\title{
The Dynamics of Aid and Political Rights
}

\author{
David Fielding
}

Department of Economics, University of Otago ${ }^{\S}$

\footnotetext{
$\S$ Address for correspondence: Department of Economics, University of Otago, PO Box 56, Dunedin 9054, New Zealand. E-mail david.fielding@otago.ac.nz; telephone +6434798653; fax +6434798174 .
} 


\section{Abstract}

Several existing papers explore the extent to which the cross-country variation in measures of democracy and political rights can be explained by the cross-country variation in foreign aid inflows. Using panel data, we explore the extent to which the variation over time in such measures can be explained by changes in aid inflows, thus providing direct evidence on the impact of innovations in donor policy, and distinguishing between the short-run and long-run effects of changes in aid. Our results are very different from those based on cross-country variation in aid inflows. We find evidence of large differences between the effect of aggregate aid and the effect of aid for political reform, and between the effects in countries at different stages of political development. There is no evidence that aid intended for political reform has achieved its objective, and in some countries it may be counter-productive. However, aggregate aid can have a beneficial effect on political rights.

JEL classification: O19

Key words: Aid, political rights, dynamic panel model 


\section{Introduction}

In the last decade, donors have paid more attention to the effect of aid on the quality of governance of recipient countries. For example, since 2004, the United States' Millennium Challenge Account explicitly tries to use aid commitments to create an incentive for political development among recipients, ${ }^{1}$ and the OECD’s Human Rights Task Team 'develops policy guidance on how to integrate human rights more consistently into donor policies and practice. $^{2}$ Political development is seen as an end in itself and as a potential factor influencing the impact of aid on wider social and economic development (Collier and Dollar, 2002).

This policy focus has stimulated a number of studies of the impact of aid on governance. The quality of governance has a number of dimensions. Some studies analyse the impact of aid on corruption and standards in public institutions. Examples of studies finding a negative impact of aid include Ali and Isse (2003), Bräutigem and Knack (2004), and Busse and Gröning (2009). Explanations for this effect include the pressure that the management of aid inflows puts on the recipient's institutional resources and the lack of an incentive to develop domestic institutions when donors create their own local infrastructure. However, empirical results typically take the form of a regression coefficient on total aid inflows, which is consistent with several different interpretations of the aid-governance nexus. Moreover, a few studies, such as Tavares (2003), find a positive aid coefficient by use a slightly different sample and different identifying restrictions in the model.

A separate group of studies explores the impact of aid on democracy and political rights. Knack (2004) finds total aid to have a negative impact on both Polity IV and Freedom House measures of political rights, on average. Subsequent studies have tried to uncover the

\footnotetext{
${ }^{1}$ See Johnson and Zajunc (2006) and Öhler et al. (2010) for analyses of the effectiveness of this policy.

${ }^{2}$ See www.oecd.org/document/21/0,3746,en_2649_34565_35901653_1_1_1_1,00.html.
} 
mechanisms that might explain such a relationship. Wright (2009) fits a model of democratic reform on aid interacted with a number of different indicators of regime type, finding some interaction terms to be positive and others negative. These differences could be interpreted as evidence on the interaction of aid inflows with the local polity. Limpach and Michaelowa (2010) measure the effect on democratisation of different types of IMF and World Bank aid packages. It appears that poverty reduction packages are most likely to promote political rights, possibly through encouraging wider participation in civil society. Sectoral aid packages are most likely to diminish political rights, possibly by reinforcing the position of political and economic elites. Kalyvitis and Vlachaki (2010) distinguish between the effect of total aid and the effect of aid designed specifically to promote good governance; governance aid has a significant positive effect on political rights.

With the exception of Busse and Gröning (2009), which does not deal explicitly with political rights, these empirical analyses are all based on pooled panel or cross-sectional datasets. Typically, the within-country variation in the data is a small fraction of the total variation, ${ }^{3}$ which is dominated by differences across countries. Approximately, the regression coefficients are measuring the effect on the difference in the quality of governance between two countries of a difference in the average level of aid inflows. For example, the Kalyvitis and Vlachaki (2010) result can be interpreted as the difference in political rights between two countries that results from a decision by donors to focus their efforts to promote good governance on one rather than the other. Favouring one particular recipient might entail more than just a larger flow of funds; it could, for example, reflect more extensive long-term institutional links between the donor and recipient

\footnotetext{
${ }^{3}$ With the main political rights indicator we will be using (voice, which described in the next section), the within-country standard deviation is about $20 \%$ of the total standard deviation.
} 
Therefore, the results from pooled panel analyses do not provide direct evidence on the effect that one can expect from an increase or reduction in aid to a particular country on political rights over the next few years. In order to provide such evidence, we will fit a dynamic panel model to a political rights dataset. We will distinguish between governance aid and total aid, and between the effects of aid to countries at different initial levels of political development. The next section discusses the data to be used. This is followed by a description of our model and a discussion of our results.

\section{Data on Political Rights and their Correlates}

\subsection{Political rights data}

Our model is designed to measure the impact of changes in governance aid on the level of political rights in a country. We will be using a dynamic panel model conditional on fixed effects, so our measure of rights must exhibit some variation over time as well as across countries; the cross-country variation in the data will be captured by a country fixed effect. This constrains our choice of data. For models of the cross-country variation in political rights, there are several plausible alternative sources of data (Teorell et al., 2010): for example, the Bertelsman Transformation Index, the Cingranelli-Richards Human Rights Dataset, Polity IV, and the Freedom House Political Rights Dataset. However, these variables are discretely distributed, and the measured annual change in political rights is equal to zero in the vast majority of cases. For a dynamic model of political rights, there is potentially more information in an aggregate of different individual measures. In the aggregate series, annual changes will be much more frequent. One such aggregate is the 'Voice and Accountability' index - henceforth voice - in the World Governance Indicators dataset (Kaufmann et al., 2009). This index combines different dimensions of civil liberties and political rights from many different sources; it also includes measures of media independence. Voice and aid data are available for 135 countries over 2002-2008; the distribution of voice is illustrated in 
Figure 1. In this figure, higher values represent more rights. The countries in the sample are listed in Appendix 1.

Variations in voice in an individual country are not a reliable indicator of political change, because the number of sources of data on which the index is based has increased over time. However, there is some consensus that the annual cross-sectional variation in the Kaufmann et al. variables is more reliable; see for example Treisman (2007) and the defence of the methodology in Kaufmann et al. (2006). In this case, the effect on the index of increases in the number of data sources does not vary systematically across countries, and it is appropriate to use voice in a panel data model that includes year fixed effects. These fixed effects will control for biases due to the increase in the number of data sources underlying the index.

There is one component of voice which itself exhibits substantial variability over time, and which can be used to test the robustness of results based on the aggregate measure. This component is the 'Freedom of the Press' index - henceforth press - published by Freedom House and documented in Teorell et al. (2010). The index is an aggregate of three sub-indices measuring different constraints on press freedom: 'Laws and Regulations', 'Political Pressures and Controls', and 'Economic Influences'. Each sub-index counts how many constraints are in place in a particular year; aggregating the sub-indices produces a scale ranging from zero (most free) to 100 (least free). Press and aid data are available for 136 countries over 1995-2008; the distribution of press is illustrated in Figure 2. In this figure, higher values represent less freedom.

\subsection{Correlates of political rights}

The key explanatory variable in our analysis is the quantity of governance aid. This variable is constructed from figures reported in the OECD Development Assistance Committee's Creditor Reporting System (CRS) database, downloaded from www.oecd.org on 01/12/2010. 
Governance aid is defined as all commitments from all donors reported in the CRS under purpose codes $15150-15170$. This includes aid to promote civil society, elections, political parties, the free flow of information, human rights, and women's equality. Further details are provided in Appendix 2. ${ }^{4}$ Aid is measured in millions of US Dollars and expressed in 2008 prices $;{ }^{5}$ our explanatory variable, governance_aid, is the logarithm of this constant-price series. ${ }^{6}$ We will assume that there is at least a one year lag between an increase in governance_aid and an increase in voice or press. Even when lagged, the aid variable might not be exogenous, and identification of the aid affect is discussed in the next section.

Changes in political rights may depend on other time-varying country characteristics. Therefore, we will also fit an extended model incorporating additional explanatory variables. These variables are not available for all countries, so their inclusion does reduce the sample size. In the following list, data are taken from the World Bank World Development Indicators unless otherwise stated; descriptive statistics are listed in Table 1.

(i) total_aid: The logarithm of total aid to each recipient. Total aid may affect political rights by improving some other dimension of social or economic development. For example, improvements in healthcare or education may enhance people's ability to participate in civil society. Total aid figures are taken from the same source as governance aid figures, and measured in the same way.

\footnotetext{
${ }^{4}$ Aid to promote public sector efficiency and the control of corruption (purpose code 15110) is excluded, so our measure is different to that of Kalyvitis and Vlachaki (2010). Conditional on fixed effects, improvements in the control of corruption are not highly correlated with improvements in political rights; see for example Fielding (2010).

${ }^{5}$ The deflators used in the constant-price series in the CRS database are recipient-specific, because for each recipient the deflator is a weighted average of donor-specific deflators, and the weights vary across recipients according to the relative importance of different donors. We use a deflator common to all recipients, based on weights for aid to all recipients in each year.

${ }^{6}$ Some individual aid observations are less than $\$ 10,000$. For these observations, governance_aid is set at $\ln (0.01)$. Our results are not highly sensitive to changing the truncation point to $\$ 1,000$ or $\$ 100,000$.
} 
(ii) population: the logarithm of the total population size. The size of political institutions is not necessarily proportional to the size of the country. There are some economies of scale in governance; for example, smaller democracies have smaller legislatures, on average, but ones that are larger relative to the size of the total population. A Dollar of governance aid spent in a small country is likely to have more impact than a Dollar spent in a large country, but the difference is not necessarily proportional to population size. Fitting a model with different coefficients on governance_aid and population allows for this non-proportionality.

(iii) disasters: the logarithm of the total number of people affected by natural disasters. ${ }^{7}$ Natural disasters often lead to states of emergency and special powers for central and local government agencies. This may lead to a deterioration in the quality of governance (Escaleras et al., 2007). The natural disasters data are taken from the database of the Centre for Research in the Epidemiology of Disasters at the Université Catholique de Louvain.

(iv) income: the logarithm of real purchasing power adjusted per capita GNP. Increases in income may improve political rights through effects similar to those of increases in total aid.

(v) trade: trade openness, as captured by the ratio of imports plus exports to GDP.

(vi) minerals: the ratio of minerals exports to GDP. An increase in the value of natural resources may encourage more authoritarian forms of government and reduce political rights, as those in power seek to ensure control of these resources. This is a form of the 'resource curse' of Collier and Hoeffler (2005).

\section{Modelling Aid Allocations}

Our aim is to identify the effect of governance aid to country $i$ in year $t$, as measured by governance_aid(i,t), on political rights in the country in the following year, as measured by voice $(i, t+1)$. We will also compare the results for voice with results for press freedom, as measured by press. First of all, we discuss a potential endogeneity problem.

\footnotetext{
${ }^{7}$ When the total number of people affected is zero, disasters is set equal to zero.
} 


\subsection{An instrument for governance aid}

Given that governance aid is unlikely to be independent of political rights, consistent estimation of an aid effect will require some identifying restriction on the political rights model. In a dynamic panel regression, restrictions on the lagged values of the endogenous regressors can be used for identification. However, it is preferable to be able to test the validity of such restrictions, which requires at least one additional instrument, an exogenous variable that affects political rights only through its effect on aid. ${ }^{8}$ Our choice of instrument is based on the finding that some types of aid depend on international media coverage. Evidence for such an effect is presented by Olsen et al. (2003), Rioux and Van Belle (2005), and Strömberg (2007). Aid can be influenced by media coverage that is not directly related to international development, because voters are inclined to express more generosity towards aid recipients with whom they are more familiar, regardless of any objective information (Small et al., 2007). However, much of the international media coverage of developing countries relates to political events, so measures of the intensity of the coverage of a given country in a given year are unlikely to be independent of political rights. Nevertheless, one source of media interest not directly related to political events is international sporting achievement. Admittedly, some sporting achievements might not be entirely independent of political rights, because they are affected by the quality of the national infrastructure, and this depends on the quality of governance. But the performance of the national soccer team is unlikely to be affected in this way, because most team members have been picked by talent scouts at an early age and play for professional clubs in industrialized countries. Therefore, our instrument for governance_aid(i,t) is a binary variable indicating whether country $i$ 's team appeared in a FIFA World Cup final in year $t$; this variable is designated finalist $(i, t)$.

\footnotetext{
${ }^{8}$ Typically, dynamic panel models have over-identifying restrictions on the lags, but without an additional instrument it is impossible to test the validity of all of these restrictions simultaneously.
} 
In order to see whether finalist $(i, t)$ is a strong instrument, we consider the following dynamic fixed-effects Tobit model of governance_aid(i,t):

$y(i, t)=\mu_{i}+\psi_{t}+\sum_{p=1}^{p=P} \lambda_{p} \cdot g o v e r n a n c e \_a i d(i, t-p)+\lambda \cdot$ finalist $(i, t)+v(i, t)$

governance_aid $(i, t)=y(i, t) \mid y(i, t) \geq y_{\min }$

governance_aid $(i, t)=y_{\min } \mid y(i, t)<y_{\min }$

In this model, the latent variable $y(i, t)$ depends on past levels of aid up to $P$ years ago and the exogenous regressor finalist $(i, t) ; \mu_{i}$ is a country fixed effect, $\psi_{t}$ a year fixed effect, and $v(i, t)$ a residual. The term $y_{\min }$ represents the truncation point of $\ln (0.01)$ discussed in footnote 6 . Wooldridge (2005) shows that the $\lambda$ parameters in equation (1) can be estimated consistently by fitting the following dynamic random-effects Tobit model:

$$
\begin{aligned}
y(i, t) & =\xi(i)+\psi_{t}+\kappa_{0} \cdot \text { governance_aid }(i, 0)+\sum_{p=1}^{p=P} \lambda_{p} \cdot \text { governance_aid(i,t-p) } \\
& +\kappa \cdot \text { finalist }(i)+\lambda \cdot \operatorname{finalist}(i, t)+v(i, t)
\end{aligned}
$$

Here, the fixed effect $\mu_{i}$ is replaced by a country-specific random effect $\xi(i)$, the initial value of aid in country $i$ (governance_aid(i,0)) and the mean value of the exogenous regressor in country $i($ finalist $(i))$. Table 2 reports the results from fitting this model to our panel of 136 countries. We need to set $P=3$ in order to ensure that $v(i, t)$ is not autocorrelated, so the sample period is $1998-2008$ (incorporating three World Cups). The estimated value of $\lambda$ is 0.61 ; this is significantly different from zero at the $5 \%$ level. Conditional on fixed effects, there is no significant correlation between finalist $(i, t)$ and any of the explanatory variables listed in section 2.2, so the significance of finalist is unlikely to be attributable to any underlying economic factor. 


\subsection{Explaining changes in political rights}

Our model is designed to measure the effect of an increase in governance aid on subsequent political rights. First, we fit the following dynamic panel model to our panel of countries over 2003-2008:

$$
\begin{aligned}
\operatorname{voice}(i, t) & =\beta_{0} \cdot \operatorname{voice}(i, t-1)+\beta_{1} \cdot \text { governance_aid }(i, t-1)+\beta_{2} \cdot \operatorname{population}(i, t-1) \\
& +\theta_{i}+\varphi_{t}+\varepsilon(i, t)
\end{aligned}
$$

Here, $\theta_{i}$ is a country fixed effect, $\varphi_{t}$ a year fixed effect, and $\varepsilon(i, t)$ is a residual. The parameter $\beta_{1}$ quantifies the change in voice that can be expected the year after an increase in governance aid, given the recipient country's population. The long-run effect of the increase is given by $\beta_{1} /\left(1-\beta_{0}\right)$. In order to deal with the endogeneity of the lagged dependent variable across the countries in the panel, we fit the model using a GMM estimator (Arellano and Bond, 1991; Blundell and Bond, 1993). Taking differences of equation (3) gives:

$$
\begin{aligned}
\Delta \operatorname{voice}(i, t) & =\beta_{0} \cdot \Delta \text { voice }(i, t-1)+\beta_{1} \cdot \Delta \text { governance_aid }(i, t-1)+\beta_{2} \cdot \Delta \text { population }(i, t-1) \\
& +\Delta \varphi_{t}+\Delta \varepsilon(i, t)
\end{aligned}
$$

Equations (3-4) are treated as a system, and the parameter $\beta_{0}$ is identified by imposing the restrictions that voice $(i, t-2)$ is orthogonal to $\Delta \varepsilon(i, t),{ }^{9}$ and that $\Delta$ voice $(i, t-2)$ is orthogonal to $\varepsilon(i, t)$. Similar moment conditions help to identify the aid effect $\beta_{1}$ : governance_aid $(i, t-2)$ is orthogonal to $\Delta \varepsilon(i, t)$, and $\Delta$ governance_aid $(i, t-2)$ is orthogonal to $\varepsilon(i, t)$. However, finalist(i,t-1) and population (i,t-1) are also used as 'ordinary' instruments in the model, so identification of the aid effect does not depend on the imposition of moment conditions.

\footnotetext{
${ }^{9}$ Moment conditions using higher-order lags of voice could also be imposed, but this would entail a very large number of instruments and risk spurious over-fitting of the endogenous regressor.
} 
It is possible that the effect of governance aid depends on the country's initial level of voice. Countries with moderately low levels of political rights may respond to aid differently from countries with very low levels. In the latter, there may be less response to outside incentives at the margin, because the generally poor quality of governance makes the polity more inflexible. For this reason, we begin by fitting equations (3-4) to subsets of countries defined by their level of voice in 2002. The first subset comprises all countries with a 2002 level of voice less than one (that is, over one worldwide standard deviation below the worldwide mean); subsequent subsets form a moving window, comprising countries with a 2002 level of voice within a certain unit interval: $[-1.9,-0.9),[-1.8,-0.8)$, and so on. Figure 3 illustrates the estimated value of $\beta_{1}$ in each window, along with its $95 \%$ confidence band. It can bee seen that most of the estimated values are insignificantly different from zero. However, values at the top end of the window, in the $[-0.1,0.9)$ interval and above, are significantly less than zero. In other words, increases in governance aid reduce the value of voice in countries where it is already high, and have no significant effect elsewhere.

Table 3 provides more detail. Column (A) in the table reports the estimated parameter values in a sample comprising all countries in which the 2002 value of voice is at least -0.1 , and column (C) the estimated parameter values in a sample comprising the remaining countries. Below the parameter values are p-values for tests of serial autocorrelation in $\Delta \varepsilon(i, t)$. These show that there is a significant amount of first-order autocorrelation, but no significant second-order autocorrelation, as we would expect if in $\varepsilon(i, t)$ is truly random. The table also includes p-values from Sargan tests on the over-identifying restrictions. The restrictions cannot be rejected in column (A), but they can be rejected in column (C). The reason for the rejection is that the moment conditions on $\Delta \varepsilon(i, t)$ are invalid, so column (D) of the table presents an alternative set of results in which these conditions are not imposed. This makes no significant difference to the estimated parameter values. 
For the high-voice sample in column (A), the estimated value of $\beta_{1}$ is -0.019 ; this implies that a doubling of governance aid ( $\Delta$ governance_aid $=0.69)$ will reduce voice by 0.013. The estimated value of $\beta_{0}$ entails that in the long run this effect would rise to 0.056 , were the doubling of aid to persist. (The standard deviation of $[$ voice $(i, t)-$ voice $(i)]$ is 0.15 , so the long-run effect represents about $35 \%$ of a standard deviation.) For the low-voice sample in column (D), there is no significant effect. Increasing governance aid has no effect in countries where governance is initially very poor; in countries where governance is initially less poor, increasing aid has a moderate negative effect.

It is possible that equation (3) omits some of the determinants of voice, and that this biases the parameter estimates. In order to check for any bias, we add the following variables to equation (3): disasters $(i, t)$, income $(i, t)$, trade $(i, t)$, minerals $(i, t)$ and total_aid $(i, t-1)$. With the exception of disasters $(i, t)$ and possibly minerals $(i, t)$, these variables are unlikely to be exogenous to voice. In the fitted model, all except disasters $(i, t)$ are treated as endogenous regressors; their effects are identified by imposing moment conditions on their lags, which are assumed to be orthogonal to $\Delta \varepsilon(i, t)$, and on their lagged differences, which are assumed to be orthogonal to $\varepsilon(i, t){ }^{10}$ It can be seen from columns (B) and (E) of Table 3 that the extended model generates similar estimates of $\beta_{0}$ and $\beta_{1}$ to those in the basic model; this gives us some confidence in the robustness of the results. Only one of the additional variables (total_aid) is individually significant at the 5\% level, and then only in the low-voice model in column (E). The point estimate of the total aid effect is 0.047 , so a doubling of total aid increases voice by 0.032 , but the high value of $\beta_{0}$ in the low-voice model means that this effect would rise to 0.43 in the long run, were the rise in aid to persist. (The standard deviation of $[\operatorname{voice}(i, t)-\operatorname{voice}(i)]$ is 0.15 , so the long-run effect represents three standard

\footnotetext{
${ }^{10}$ We should note a caveat: unlike the basic model, the extended model requires the moment conditions for identification of the aid effects.
} 
deviations.) One interpretation of this effect is that a higher total level of aid gradually improves social and economic conditions in the country, and that this improvement gradually leads to greater political rights.

These results are based on the assumption that aid commitments affect political rights only with a lag. This assumption can be tested by adding governance_aid(i,t) to the right hand side of equation (3), with finalist(i,t) as an instrument. When we make this addition, the coefficient on the extra variable is insignificantly different from zero, regardless of whether governance_aid(i,t-1) or any of the other regressors is included in the model. This suggests that our assumption is correct.

The results have stark policy implications. Improvements in political rights can be achieved through general aid to countries at the bottom end of the rights distribution, but aid designed to improve governance directly is ineffective in these countries, and counterproductive in others. These conclusions are based on a single measure of political rights. In order to explore the robustness of our conclusions, we also fit a model using an alternative measure, press. This is a discrete variable, a count of the number of press freedoms lacking in a given country in a given year, so it is appropriate to fit a Poisson model to the data. A dynamic fixed-effects Poisson model analogous to equation (3) is:

$$
\begin{aligned}
\mathrm{E}[\operatorname{press}(i, t)] & =\delta_{i} \cdot \exp \left(\alpha_{0} \cdot \operatorname{press}(i, t-1)+\alpha_{1} \cdot \text { governance_aid }(i, t-1)\right. \\
& \left.+\alpha_{2} \cdot \text { population }(i, t-1)+\zeta_{t}\right)
\end{aligned}
$$

Here, E[.] indicates the mean of a Poisson distribution, $\delta_{i}$ is a country fixed effect and $\zeta_{t}$ is a year fixed effect. The parameter $\alpha_{1}$ quantifies the proportional change in press that can be expected the year after an increase in governance aid, given the recipient country's population. The right hand side of equation (5) contains two lagged variables - press and governance_aid - that are not exogenous across the panel of countries. Following 
Wooldridge (2005), we deal with the endogeneity here by fitting the following dynamic random-effects Poisson model to our sample of countries over 1996-2008:

$$
\begin{aligned}
\mathrm{E}[\operatorname{press}(i, t)] & =v(i) \cdot \exp \left(\alpha_{0} \cdot \operatorname{press}(i, t-1)+\gamma_{0} \cdot \operatorname{press}(i, 0)\right. \\
& +\alpha_{1} \cdot \text { governance_aid }(i, t-1)+\gamma_{1} \cdot \operatorname{governance\_ aid}(i, 0) \\
& \left.+\alpha_{2} \cdot \text { population }(i, t-1)+\gamma_{2} \cdot \operatorname{population}(i)+\zeta_{t}\right)
\end{aligned}
$$

Here, the fixed effect $\delta_{i}$ is replaced by a country-specific random effect $v(i)$, the initial values of press and governance_aid in country $i$, and the mean value of the exogenous regressor in country $i$ (population(i)).

Again, the effect of aid might depend on the initial value of the political rights variable. We therefore begin by fitting equation (6) to subsets of countries defined by their level of press in 1995. The first subset comprises all countries with a 1995 level of press no greater than 35; subsequent subsets form a moving window, comprising countries with a 1995 level of press within a certain 25-point interval: $(15,40],(20,45]$, and so on. Figure 4 illustrates the estimated value of $\alpha_{1}$ in each window, along with its $95 \%$ confidence band. In comparing Figures 3 and 4, recall that higher levels of voice and lower levels of press indicate more freedom. The positive and significant values of $\alpha_{1}$ for low initial values of press are therefore consistent with the negative and significant values of $\beta_{1}$ for high initial values of voice. The insignificant values of $\alpha_{1}$ for high initial values of press are consistent with the insignificant values of $\beta_{1}$ for low initial values of voice. When the initial value of press is no greater than 35 (a relatively high level of press freedom), increases in aid lead to significantly less freedom; otherwise, aid has no significant effect.

Table 4 provides more detail. Column (A) in the table reports the estimated parameter values in a sample comprising all countries in which the 1995 value of press is no greater than 35, and column (B) the estimated parameter values in a sample comprising the 
remaining countries. For the low-press sample in column (A), the estimated value of $\alpha_{1}$ is 0.01 . When the regression is augmented with the extra regressors, disasters $(i, t)$, income $(i, t)$, trade $(i, t)$, minerals $(i, t)$ and total_aid $(i, t-1)$, the coefficients on these variables are not significantly different from zero. Overall, the results regarding governance aid and political rights are similar when rights are measured by press instead of voice.

\section{Discussion}

Previous research has found a positive relationship between the variation in political rights across countries and the variation in governance aid. We find a negative relationship between the variation in political rights over time (in some countries) and the variation in governance aid. Moreover, the explanation for this asymmetry does not lie in differences in variable definition or sample size: as discussed in Appendix 3, it is possible, using our data, to replicate the positive relationship in the cross-country variation. One explanation for the asymmetry is that the countries receiving large amounts of governance aid have better institutional links with donors. It may be the donor engagement rather than the injection of cash that produces better political outcomes. By contrast, increasing the amount of governance aid to a particular country worsens political outcomes, if it makes any difference at all. There are a number of possible explanations for this effect. It may be that for a given level of institutional engagement, an increased cash flow is interpreted as a signal of approval for the recipient regime that indicates a relaxation of political conditionality. Alternatively, managing aid inflows puts pressure on the resources of civil society groups, worsening their overall level of effectiveness.

Some previous research has found a negative relationship, on average, between the variation in political rights across countries and the variation in total aid. However, it appears that the effect depends on the recipient country's regime type, and for some types of regime the relationship is positive. We find a positive relationship between the variation in political 
rights over time (in some countries) and the variation in total aid. This reinforces the result that aid can sometimes lead to improvements in political rights. The ability of donors to promote political rights depends on an understanding of the institutional characteristics that influence aid effectiveness.

\section{References}

Ali, M.A, Isse, H.S. (2003). Determinants of economic corruption: a cross-country comparison. Cato Journal, 22(3), 449-466.

Arellano, M., Bond, S. (1991). Some tests of specification for panel data: Monte-Carlo evidence and an application to employment equations. Review of Economic Studies, 58, 277-97.

Blundell, R., Bond, S. (1998). Initial conditions and moment restrictions in dynamic paneldata models. Journal of Econometrics, 87, 115-43.

Bräutigam, D.A., Knack, S. (2004). Foreign aid, institutions, and governance in Sub-Saharan Africa. Economic Development and Cultural Change, 52(2), 255-285.

Busse, M., Gröning, S. (2009). Does foreign aid improve governance? Economics Letters, $104,76-78$.

Collier, P., Dollar, D. (2002). Aid allocation and poverty reduction. European Economic Review, 46(8), 1475-1500.

Collier, P., Hoeffler, A. (2005). Resource rents, governance and conflict. Journal of Conflict Resolution, 49(4), 625-633.

Escaleras, M., Anbarci, N., Register, C.A. (2007). Public sector corruption and major earthquakes: a potentially deadly interaction. Public Choice, 132, 209-230.

Fielding, D. (2010). Health aid and governance in developing countries. Health Economics (forthcoming; doi: 10.1002/hec.1631). 
Johnson, D., Zajunc, T. (2006). Can foreign aid create an incentive for good governance? Evidence from the Millennium Challenge Corporation. Mimeo, Harvard University.

Kalyvitis, S., Vlachaki, I. (2010). Democratic aid and the democratization of recipients. Contemporary Economic Policy, 28(2), 188-218.

Kaufmann, D., Kraay, A., Mastruzzi, M. (2006). Growth and governance: a reply. Journal of Politics, 69(2), 555-562.

Kaufmann, D., Kraay, A., Mastruzzi, M. (2009). Governance Matters VIII: aggregate and individual governance indicators 1996-2008. Policy Research Working Paper 4978, The World Bank, Washington, D.C.

Knack, S. (2004). Does foreign aid promote democracy? International Studies Quarterly, 48(1), 251-266.

Limpach, S., Michaelowa, K. (2010). The impact of World Bank and IMF programs on democratization in developing countries. Working Paper 62, Center for Comparative and International Studies, Zürich University.

Öhler, H., Nunnenkamp, P., Dreher, A. (2010). Does conditionality work? A test for an innovative US aid scheme. Discussion Paper 103, Center for European Governance and Economic Development, Georg August University, Göttingen.

Olsen, G.R., Carstensen, N., Hønyen, K. (2003). Humanitarian crises: what determines the level of emergency assistance? Disasters, 27(2), 109-126.

Rioux, J-S., Van Belle, D.A. (2005). The influence of Le Monde coverage on French foreign aid allocations. International Studies Quarterly, 49, 481-502.

Small, D., Loewenstein, G., Slovic, P. (2007). Sympathy and callousness: the impact of deliberative thought on donations to identifiable and statistical victims. Organizational Behaviour and Human Decision Processes, 102, 143-153. 
Strömberg, D. (2007). Natural disasters, economic development, and humanitarian aid. Journal of Economic Perspectives, 21(3), 199-222.

Tavares, J. (2003). Does Foreign Aid Corrupt? Economic Letters, 79, 99-106.

Teorell, J., Samanni, M., Charron, N., Holmberg, S., Rothstein, B. (2010). The Quality of Government Dataset (version 27). Quality of Government Institute, University of Gothenburg.

Treisman, D. (2007). What have we learned about the causes of corruption from ten years of cross-national empirical research? Annual Review of Political Science, 10, 211-244.

Wooldridge, J.M. (2005). Simple solutions to the initial conditions problem in dynamic, nonlinear panel data models with unobserved heterogeneity. Journal of Applied Econometrics, 20, 39-54.

Wright, J. (2009). How foreign aid can foster democratization in authoritarian regimes. American Journal of Political Science, 53(3), 552-571. 


\section{Appendix 1: Countries Included in the Sample}

Column headings here indicate columns in Tables 3-4. A cross indicates that the country is part of the sample in that column.

\begin{tabular}{|c|c|c|c|c|c|c|c|c|c|c|c|c|c|c|c|c|c|c|c|c|c|c|c|c|c|c|c|}
\hline & $3 \mathrm{~A}$ & 3B & $3 \mathrm{D}$ & $3 \mathrm{E}$ & $4 \mathrm{~A}$ & 4B & & $3 \mathrm{~A}$ & $3 B$ & $3 \mathrm{D}$ & $3 \mathrm{E}$ & $4 \mathrm{~A}$ & $4 \mathrm{~B}$ & & $3 \mathrm{~A}$ & $3 \mathrm{~B}$ & $3 \mathrm{D}$ & $3 \mathrm{E}$ & $4 \mathrm{~A}$ & $4 \mathrm{~B}$ & & $3 \mathrm{~A}$ & $3 \mathrm{~B}$ & $3 \mathrm{D}$ & $3 \mathrm{E}$ & $4 \mathrm{~A}$ & 4B \\
\hline Albania & $\mathrm{X}$ & $\mathrm{X}$ & & & $\mathrm{X}$ & & Djibouti & & & $\mathrm{X}$ & & $\mathrm{X}$ & & Liberia & & & $\mathrm{X}$ & & $\mathrm{X}$ & & Serbia & & & $\mathrm{X}$ & $\mathrm{X}$ & $\mathrm{X}$ & \\
\hline Algeria & & & $\mathrm{X}$ & $\mathrm{X}$ & $\mathrm{X}$ & & Dominica & $\mathrm{X}$ & $\mathrm{X}$ & & & & $\mathrm{X}$ & Libya & & & $\mathrm{X}$ & & $\mathrm{X}$ & & Seychelles & $\mathrm{X}$ & $\mathrm{X}$ & & & $\mathrm{X}$ & \\
\hline Angola & & & $\mathrm{X}$ & & $\mathrm{X}$ & & Dom. Rep. & $\mathrm{X}$ & $\mathrm{X}$ & & & $\mathrm{X}$ & & Macedonia & & & $\mathrm{X}$ & $\mathrm{X}$ & $\mathrm{X}$ & & Sierra Leone & & & $\mathrm{X}$ & & $\mathrm{X}$ & \\
\hline Antigua & $\mathrm{X}$ & $\mathrm{X}$ & & & & $\mathrm{X}$ & Ecuador & $\mathrm{X}$ & $\mathrm{X}$ & & & $\mathrm{X}$ & & Madagascar & & & $\mathrm{X}$ & $\mathrm{X}$ & & $\mathrm{X}$ & Solomon Is. & $\mathrm{X}$ & & & & & $\mathrm{X}$ \\
\hline Argentina & $X$ & $\mathrm{X}$ & & & & $\mathrm{X}$ & Egypt & & & $\mathrm{X}$ & $\mathrm{X}$ & $\mathrm{X}$ & & Malawi & & & $\mathrm{X}$ & $\mathrm{X}$ & $\mathrm{X}$ & & Somalia & & & $\mathrm{X}$ & & $\mathrm{X}$ & \\
\hline Armenia & & & $\mathrm{X}$ & $\mathrm{X}$ & $\mathrm{X}$ & & El Salvador & $\mathrm{X}$ & $\mathrm{X}$ & & & $\mathrm{X}$ & & Malaysia & & & $\mathrm{X}$ & $\mathrm{X}$ & $\mathrm{X}$ & & South Africa & $\mathrm{X}$ & $\mathrm{X}$ & & & & $\mathrm{X}$ \\
\hline Azerbaijan & & & $\mathrm{X}$ & $\mathrm{X}$ & $\mathrm{X}$ & & Eq. Guinea & & & $\mathrm{X}$ & & $\mathrm{X}$ & & Maldives & & & $\mathrm{X}$ & $\mathrm{X}$ & $\mathrm{X}$ & & Sri Lanka & & & $\mathrm{X}$ & $\mathrm{X}$ & $\mathrm{X}$ & \\
\hline Bangladesh & & & $\mathrm{X}$ & $X$ & $\mathrm{X}$ & & Eritrea & & & $\mathrm{X}$ & $\mathrm{X}$ & $\mathrm{X}$ & & Mali & $\mathrm{X}$ & $\mathrm{X}$ & & & & $X$ & St. Kitts & $\mathrm{X}$ & $\mathrm{X}$ & & & & $\mathrm{X}$ \\
\hline Barbados & $X$ & & & & & $\mathrm{X}$ & Ethiopia & & & $\mathrm{X}$ & $\mathrm{X}$ & $\mathrm{X}$ & & Marshall Is. & $\mathrm{X}$ & & & & & $\mathrm{X}$ & St. Lucia & $\mathrm{X}$ & $\mathrm{X}$ & & & & $\mathrm{X}$ \\
\hline Belarus & & & $\mathrm{X}$ & $\mathrm{X}$ & $\mathrm{X}$ & & Fiji & $\mathrm{X}$ & $\mathrm{X}$ & & & $\mathrm{X}$ & & Mauritania & & & $\mathrm{X}$ & $\mathrm{X}$ & $\mathrm{X}$ & & St. Vincent & $\mathrm{X}$ & $\mathrm{X}$ & & & & $X$ \\
\hline Belize & $X$ & $\mathrm{X}$ & & & & $\mathrm{X}$ & Gabon & & & $\mathrm{X}$ & $\mathrm{X}$ & $\mathrm{X}$ & & Mauritius & $\mathrm{X}$ & $\mathrm{X}$ & & & & $\mathrm{X}$ & Sudan & & & $\mathrm{X}$ & $\mathrm{X}$ & $\mathrm{X}$ & \\
\hline Benin & $X$ & $\mathrm{X}$ & & & & $X$ & Gambia & & & $\mathrm{X}$ & $\mathrm{X}$ & $\mathrm{X}$ & & Mexico & $\mathrm{X}$ & $\mathrm{X}$ & & & $\mathrm{X}$ & & Suriname & $\mathrm{X}$ & $\mathrm{X}$ & & & & $\mathrm{X}$ \\
\hline Bhutan & & & $\mathrm{X}$ & $X$ & $\mathrm{X}$ & & Georgia & & & $\mathrm{X}$ & $\mathrm{X}$ & $X$ & & Micronesia & $\mathrm{X}$ & & & & & $\mathrm{X}$ & Swaziland & & & $\mathrm{X}$ & $\mathrm{X}$ & $\mathrm{X}$ & \\
\hline Bolivia & $\mathrm{X}$ & $\mathrm{X}$ & & & & $\mathrm{X}$ & Ghana & $\mathrm{X}$ & $\mathrm{X}$ & & & $\mathrm{X}$ & & Moldova & & & $\mathrm{X}$ & $\mathrm{X}$ & $\mathrm{X}$ & & Syria & & & $\mathrm{X}$ & $\mathrm{X}$ & $\mathrm{X}$ & \\
\hline Bosnia & & & $\mathrm{X}$ & $X$ & $\mathrm{X}$ & & Grenada & $\mathrm{X}$ & $\mathrm{X}$ & & & & $\mathrm{X}$ & Mongolia & $\mathrm{X}$ & $\mathrm{X}$ & & & & $\mathrm{X}$ & Tajikistan & & & $\mathrm{X}$ & & $\mathrm{X}$ & \\
\hline Botswana & $X$ & $\mathrm{X}$ & & & & $\mathrm{X}$ & Guatemala & & & $\mathrm{X}$ & $\mathrm{X}$ & $\mathrm{X}$ & & Morocco & & & $\mathrm{X}$ & $\mathrm{X}$ & $\mathrm{X}$ & & Tanzania & & & $\mathrm{X}$ & $\mathrm{X}$ & $\mathrm{X}$ & \\
\hline Brazil & $X$ & $\mathrm{X}$ & & & & $\mathrm{X}$ & Guinea & & & $\mathrm{X}$ & $\mathrm{X}$ & $X$ & & Mozambique & & & $\mathrm{X}$ & $X$ & $\mathrm{X}$ & & Thailand & $\mathrm{X}$ & $\mathrm{X}$ & & & & $\mathrm{X}$ \\
\hline Burkina Faso & & & $\mathrm{X}$ & $\mathrm{X}$ & $\mathrm{X}$ & & Guinea-Bissau & & & $\mathrm{X}$ & $\mathrm{X}$ & $\mathrm{X}$ & & Myanmar & & & $\mathrm{X}$ & & $\mathrm{X}$ & & Timor-Leste & $\mathrm{X}$ & & & & & $\mathrm{X}$ \\
\hline Burundi & & & $\mathrm{X}$ & $\mathrm{X}$ & $\mathrm{X}$ & & Guyana & $\mathrm{X}$ & $\mathrm{X}$ & & & & $\mathrm{X}$ & Namibia & $\mathrm{X}$ & $\mathrm{X}$ & & & & $\mathrm{X}$ & Togo & & & $\mathrm{X}$ & $\mathrm{X}$ & $\mathrm{X}$ & \\
\hline Cambodia & & & $\mathrm{X}$ & $\mathrm{X}$ & $\mathrm{X}$ & & Haiti & & & $\mathrm{X}$ & & $\mathrm{X}$ & & Nepal & & & $\mathrm{X}$ & $\mathrm{X}$ & $\mathrm{X}$ & & Tonga & $\mathrm{X}$ & $\mathrm{X}$ & & & & $\mathrm{X}$ \\
\hline Cameroon & & & $\mathrm{X}$ & $\mathrm{X}$ & $\mathrm{X}$ & & Honduras & & & $\mathrm{X}$ & $\mathrm{X}$ & & $\mathrm{X}$ & Nicaragua & & & $\mathrm{X}$ & $\mathrm{X}$ & $\mathrm{X}$ & & Trinidad & $\mathrm{X}$ & $\mathrm{X}$ & & & & $\mathrm{X}$ \\
\hline Cape Verde & $\mathrm{X}$ & $\mathrm{X}$ & & & & $\mathrm{X}$ & India & $\mathrm{X}$ & $\mathrm{X}$ & & & $\mathrm{X}$ & & Niger & & & $\mathrm{X}$ & $\mathrm{X}$ & $\mathrm{X}$ & & Tunisia & & & $\mathrm{X}$ & $\mathrm{X}$ & $\mathrm{X}$ & \\
\hline C.A.R. & & & $\mathrm{X}$ & $X$ & $\mathrm{X}$ & & Indonesia & & & $\mathrm{X}$ & $\mathrm{X}$ & $\mathrm{X}$ & & Nigeria & & & $\mathrm{X}$ & $X$ & $\mathrm{X}$ & & Turkey & & & $\mathrm{X}$ & $\mathrm{X}$ & $\mathrm{X}$ & \\
\hline Chad & & & $\mathrm{X}$ & & $\mathrm{X}$ & & Iran & & & $\mathrm{X}$ & $\mathrm{X}$ & $\mathrm{X}$ & & N. Korea & & & $\mathrm{X}$ & & $\mathrm{X}$ & & Turkmenistan & & & $\mathrm{X}$ & & $\mathrm{X}$ & \\
\hline Chile & $\mathrm{X}$ & $\mathrm{X}$ & & & & $\mathrm{X}$ & Iraq & & & & & $\mathrm{X}$ & & Oman & & & $\mathrm{X}$ & $\mathrm{X}$ & $\mathrm{X}$ & & Uganda & & & $\mathrm{X}$ & $\mathrm{X}$ & $\mathrm{X}$ & \\
\hline China & & & $\mathrm{X}$ & $\mathrm{X}$ & $\mathrm{X}$ & & Jamaica & $\mathrm{X}$ & & & & & $\mathrm{X}$ & Pakistan & & & $\mathrm{X}$ & $\mathrm{X}$ & $\mathrm{X}$ & & Ukraine & & & $\mathrm{X}$ & $\mathrm{X}$ & $\mathrm{X}$ & \\
\hline Colombia & & & $\mathrm{X}$ & $\mathrm{X}$ & $\mathrm{X}$ & & Jordan & & & $\mathrm{X}$ & $\mathrm{X}$ & $\mathrm{X}$ & & Panama & $\mathrm{X}$ & $\mathrm{X}$ & & & & $\mathrm{X}$ & Uruguay & $\mathrm{X}$ & $\mathrm{X}$ & & & & $\mathrm{X}$ \\
\hline Comoros & & & $X$ & & & $\mathrm{X}$ & Kazakhstan & & & $\mathrm{X}$ & $\mathrm{X}$ & $\mathrm{X}$ & & P.N.G. & $\mathrm{X}$ & $\mathrm{X}$ & & & & $\mathrm{X}$ & Uzbekistan & & & $\mathrm{X}$ & & $\mathrm{X}$ & \\
\hline Congo Rep. & & & $\mathrm{X}$ & & $\mathrm{X}$ & & Kenya & & & $\mathrm{X}$ & $\mathrm{X}$ & $\mathrm{X}$ & & Paraguay & & & $\mathrm{X}$ & $\mathrm{X}$ & $\mathrm{X}$ & & Vanuatu & $\mathrm{X}$ & $\mathrm{X}$ & & & $\mathrm{X}$ & \\
\hline Costa Rica & $\mathrm{X}$ & $\mathrm{X}$ & & & & $\mathrm{X}$ & Kiribati & $\mathrm{X}$ & & & & & $\mathrm{X}$ & Peru & $\mathrm{X}$ & $\mathrm{X}$ & & & $\mathrm{X}$ & & Venezuela & & & $\mathrm{X}$ & $\mathrm{X}$ & & $\mathrm{X}$ \\
\hline Côte d'Ivoire & & & $\mathrm{X}$ & $X$ & $\mathrm{X}$ & & Kyrgyzstan & & & $\mathrm{X}$ & $\mathrm{X}$ & $\mathrm{X}$ & & Philippines & $\mathrm{X}$ & $\mathrm{X}$ & & & $\mathrm{X}$ & & Vietnam & & & $\mathrm{X}$ & $X$ & $\mathrm{X}$ & \\
\hline Croatia & $\mathrm{X}$ & $\mathrm{X}$ & & & $\mathrm{X}$ & & Laos & & & $\mathrm{X}$ & & $\mathrm{X}$ & & Rwanda & & & $\mathrm{X}$ & $\mathrm{X}$ & $\mathrm{X}$ & & Yemen & & & $\mathrm{X}$ & $\mathrm{X}$ & $\mathrm{X}$ & \\
\hline Cuba & & & $\mathrm{X}$ & & $\mathrm{X}$ & & Lebanon & & & $\mathrm{X}$ & $\mathrm{X}$ & $\mathrm{X}$ & & Samoa & $\mathrm{X}$ & $X$ & & & & $\mathrm{X}$ & Zambia & & & $\mathrm{X}$ & $\mathrm{X}$ & $\mathrm{X}$ & \\
\hline D.R.C. & & & $\mathrm{X}$ & & $\mathrm{X}$ & & Lesotho & $\mathrm{X}$ & $\mathrm{X}$ & & & $\mathrm{X}$ & & Senegal & $\mathrm{X}$ & $\mathrm{X}$ & & & & $\mathrm{X}$ & Zimbabwe & & & $\mathrm{X}$ & & $\mathrm{X}$ & \\
\hline
\end{tabular}




\section{Appendix 2: Governance Aid Codes and Descriptions}

\begin{tabular}{|c|c|}
\hline CRS Code & Description \\
\hline $\begin{array}{l}\text { 15150: democratic } \\
\text { participation and civil } \\
\text { society }\end{array}$ & $\begin{array}{l}\text { 'Support to the exercise of democracy and diverse forms of } \\
\text { participation of citizens beyond elections; direct democracy instruments } \\
\text { such as referenda and citizens' initiatives; support to organisations to } \\
\text { represent and advocate for their members, to monitor, engage and hold } \\
\text { governments to account, and to help citizens learn to act in the public } \\
\text { sphere; curricula and teaching for civic education at various levels. } \\
\text { Electoral management bodies and processes, election observation, } \\
\text { voters' education.' }\end{array}$ \\
\hline 15151: elections & $\begin{array}{l}\text { 'Electoral management bodies and processes, election observation, } \\
\text { voters' education.' }\end{array}$ \\
\hline $\begin{array}{l}\text { 15152: legislatures and } \\
\text { political parties }\end{array}$ & $\begin{array}{l}\text { 'Assistance to strengthen key functions of legislatures / parliaments } \\
\text { including subnational assemblies and councils (representation; } \\
\text { oversight; legislation), such as improving the capacity of legislative } \\
\text { bodies, improving legislatures committees and administrative } \\
\text { procedures; research and information management systems; providing } \\
\text { training programmes for legislators and support personnel. Assistance } \\
\text { to political parties and strengthening of party systems.' }\end{array}$ \\
\hline $\begin{array}{l}\text { 15153: media and free } \\
\text { flow of information }\end{array}$ & $\begin{array}{l}\text { 'Activities that support free and uncensored flow of information on } \\
\text { public issues; activities that increase the editorial and technical skills } \\
\text { and the integrity of the print and broadcast media, e.g. training of } \\
\text { journalists.' }\end{array}$ \\
\hline 15160: human rights & $\begin{array}{l}\text { 'Measures to support specialised official human rights institutions and } \\
\text { mechanisms at universal, regional, national and local levels in their } \\
\text { statutory roles to promote and protect civil and political, economic, } \\
\text { social and cultural rights as defined in international conventions and } \\
\text { covenants; translation of international human rights commitments into } \\
\text { national legislation; reporting and follow-up; human rights dialogue. } \\
\text { Human rights defenders and human rights NGOs; human rights } \\
\text { advocacy, activism, mobilisation; awareness raising and public human } \\
\text { rights education. Human rights programming targeting specific groups, } \\
\text { e.g. children, persons with disabilities, migrants, ethnic, religious, } \\
\text { linguistic and sexual minorities, indigenous people and those suffering } \\
\text { from caste discrimination, victims of trafficking, victims of torture.' }\end{array}$ \\
\hline $\begin{array}{l}\text { 15170: women's } \\
\text { equality organisations } \\
\text { and institutions }\end{array}$ & $\begin{array}{l}\text { 'Support for institutions and organisations (governmental and non- } \\
\text { governmental), working for gender equality and women's } \\
\text { empowerment.' }\end{array}$ \\
\hline
\end{tabular}

Source: OECD Development Assistance Committee 


\section{Appendix 3: Modelling the Cross-Country Variation in voice}

As noted in the main text, the within-country variation in voice is much smaller than the overall variation across the countries in the panel, and the mechanisms driving the betweencountry variation in voice may be very different from those driving the within-country variation. In order to explore the between-country variation, we fit the following randomeffects model:

$\operatorname{voice}(i, t)=\pi(i)+\rho \cdot$ governance_aid $(i, t-1)+\omega \cdot$ population $(i, t-1)+\chi(i, t)$

Here, $\pi(i)$ is a country-specific random effect and $\chi(i, t)$ is an error term. As we will see, estimates of the parameters in equation (A1) are driven by the between-country variation in the data.

Table A1 reports the parameters of three regressions based on equation (A1). The first (column A) is an a standard random-effects model, treating governance_aid(i,t-1) as exogenous. The second (column B) is an Instrumental Variables model fitted using Baltagi's EC2SLS estimator, with finalist(i,t-1) as an instrument for governance_aid(i,t-1). The third (column $\mathrm{C}$ ) is an EC2SLS estimate with additional regressors, which are assumed to be exogenous: disasters, minerals, dummy variables for former British / French colonies, and continent dummies. (These dummy variables are time-invariant, so they do not appear in the fixed-effects models in the main text.) The $\rho$ parameter is significantly greater than zero in all three columns, indicating that countries receiving more aid have more political rights in the following year. However, the size of the coefficient varies substantially, so estimates of the effect are sensitive to whether governance_aid(i,t-1) is treated as exogenous, and whether we control for the effect of other determinants of political rights.

The bottom of the table reports the overall $\mathrm{R}^{2}$ of each regression, along with the within-country and between-country $\mathrm{R}^{2} \mathrm{~s}$. The basic model in columns A-B explains about 
$20 \%$ of the between-country variation in voice $(i, t)$, and the extended model in column $\mathrm{C}$ about a half. The model explains almost none of the within-country variation, so the parameter estimates can be interpreted, approximately, as the effect on the country mean voice( $i)$ of variation in each of the explanatory variables from one country to another. The estimates in column $\mathrm{C}$ are probably the most reliable, and here $\rho=0.033$. The standard deviation of governance_aid(i,t) in the sample is about 1.8 , so in a country with a level of aid one standard deviation higher one can expect the level of voice to be higher by 0.06 , that is, by $6 \%$ of its worldwide standard deviation, or about $7 \%$ of its deviation in the sample. Countries attracting a high level of governance aid (on average) do have a higher level of political rights (on average). 
Figure 1: Histogram for voice

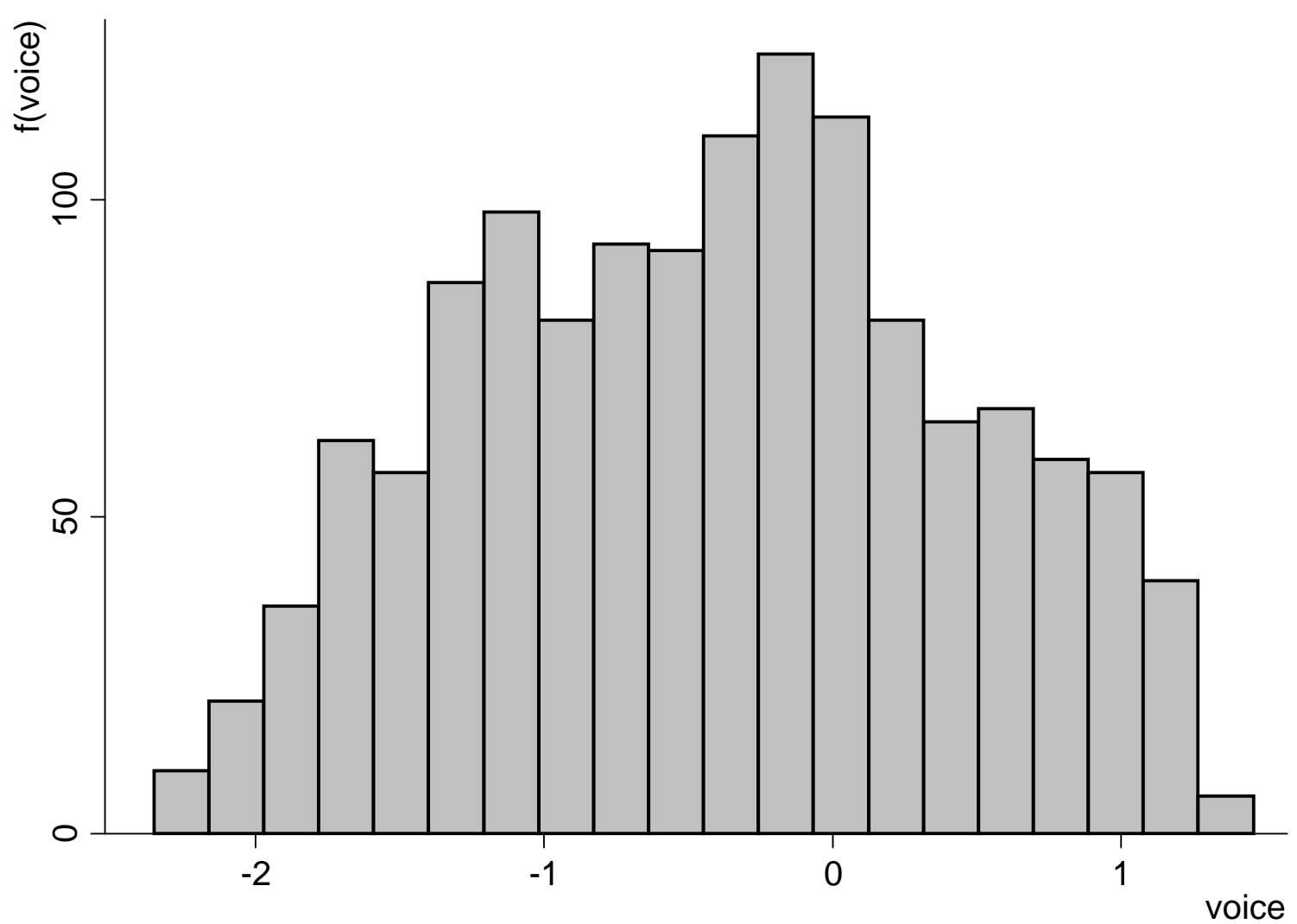

Figure 2: Histogram for press

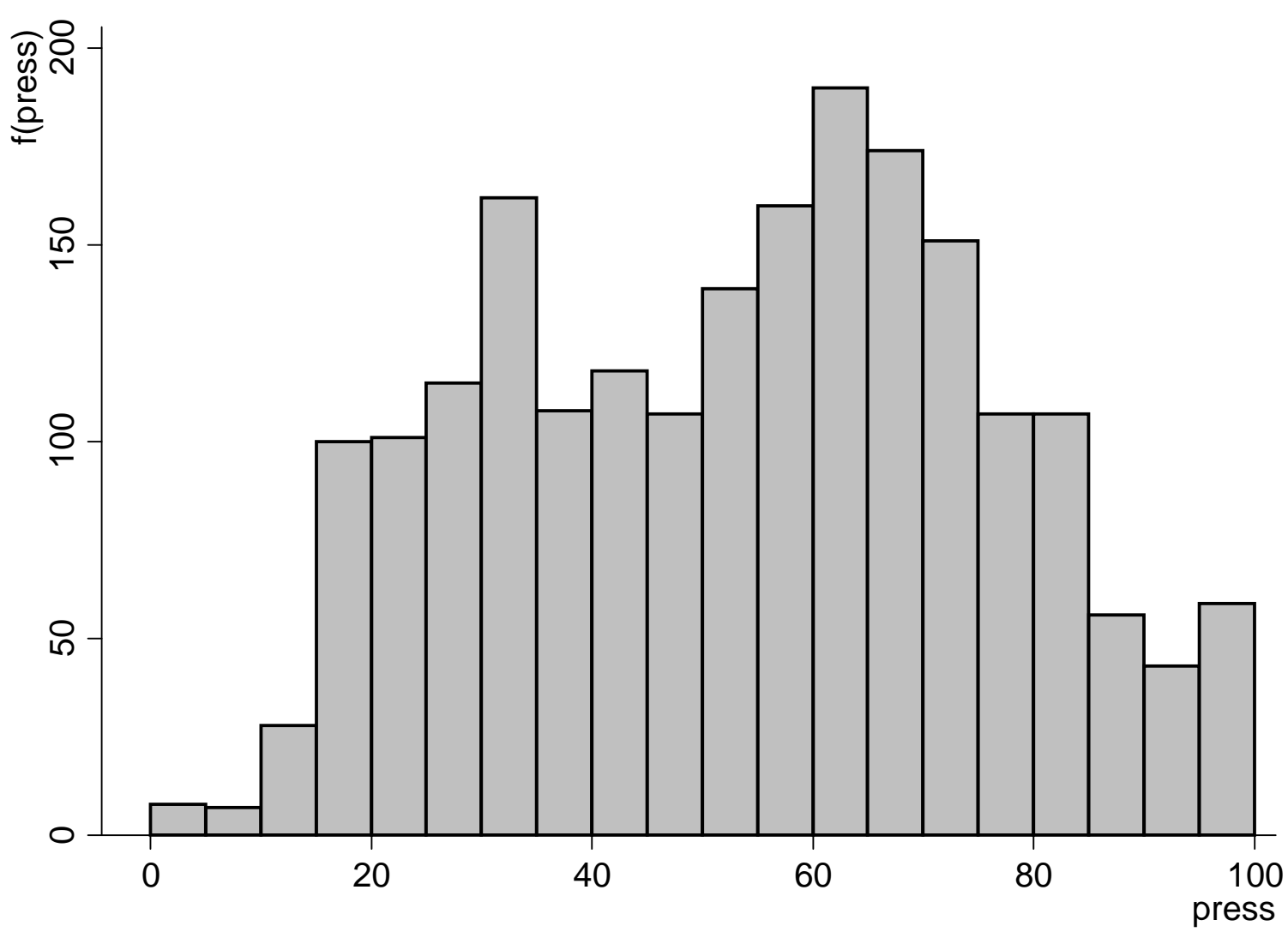


Figure 3: Recursive Plot of the governance_aid Coefficient in the voice Model The vertical axis indicates the coefficient value and the horizontal axis the upper bound of the sub-sample used (the value of voice in 2002). Grey lines indicate the 95\% confidence band.

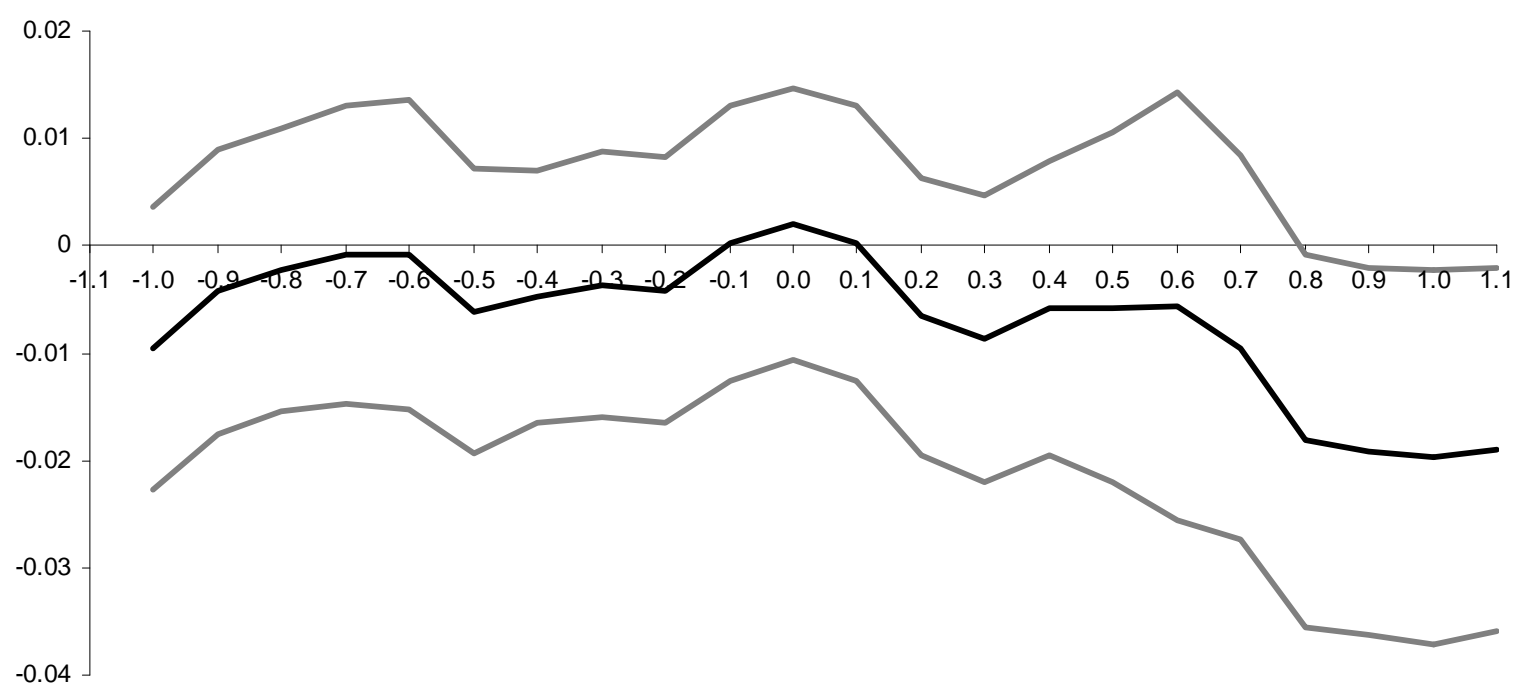

Figure 4: Recursive Plot of the governance_aid Coefficient in the press Model

The vertical axis indicates the coefficient value and the horizontal axis the upper bound of the sub-sample used (the value of press in 1995). Grey lines indicate the 95\% confidence band.

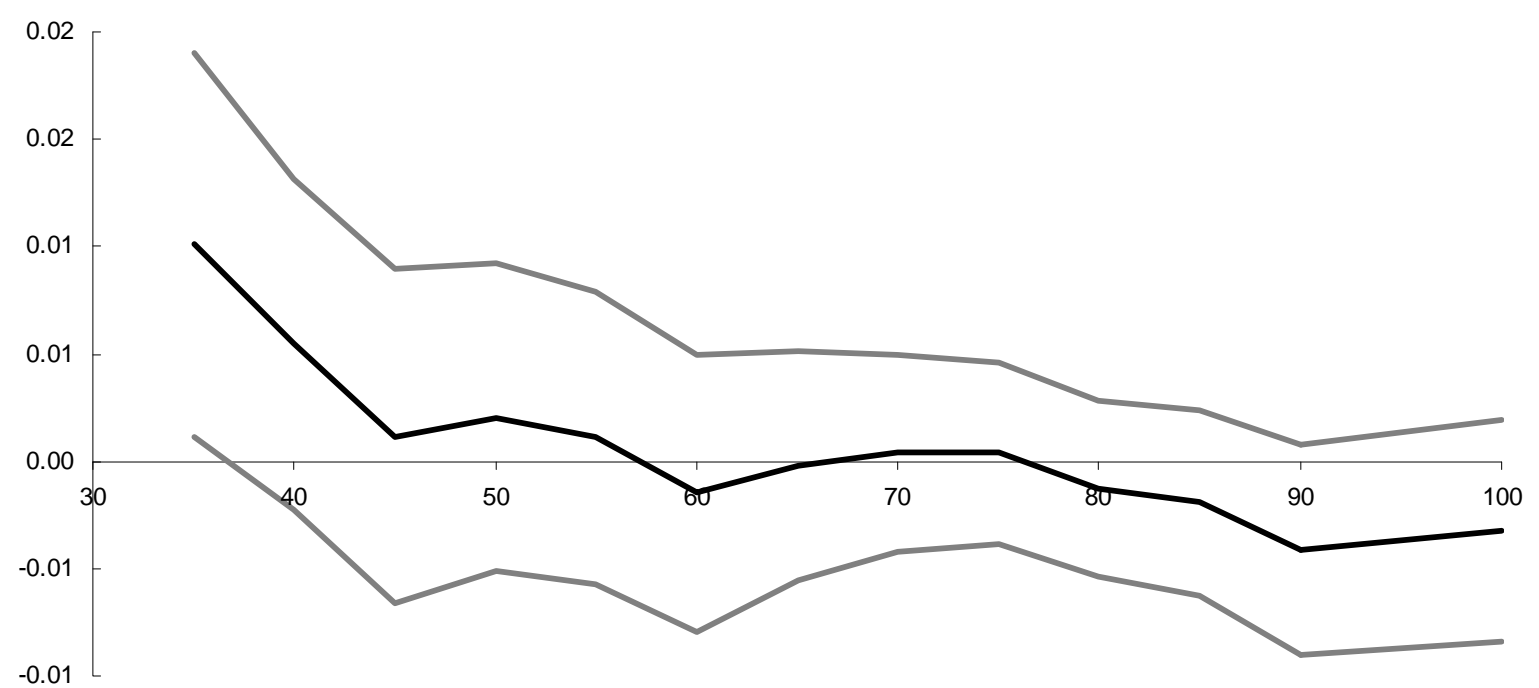


Table 1: Descriptive Statistics

\begin{tabular}{|c|c|c|c|c|c|c|}
\hline variable & years & countries & observations & mean & std. dev. & $\begin{array}{l}\text { std. dev. around } \\
\text { fixed effects }\end{array}$ \\
\hline $\operatorname{voice}(i, t)$ & 2003-2008 & 135 & 810 & 0.414 & 0.846 & 0.149 \\
\hline $\operatorname{press}(i, t)$ & $1996-2008$ & 136 & 1768 & 53.37 & 22.30 & 6.558 \\
\hline population $(i, t-1)$ & 1996-2008 & 136 & 1760 & 15.52 & 2.043 & 0.078 \\
\hline disasters $(i, t)$ & $1996-2008$ & 136 & 1768 & 6.397 & 5.532 & 3.959 \\
\hline trade $(i, t)$ & 1996-2008 & 130 & 1629 & 0.836 & 0.400 & 0.149 \\
\hline minerals $(i, t)$ & $1996-2008$ & 108 & 1213 & 0.081 & 0.125 & 0.047 \\
\hline
\end{tabular}

* Figures are for the 1320 of the 1768 observations of governance_aid above the truncation value of $\ln (0.01)$. 
Table 2: A Model of Governance Aid

The coefficients are estimated using a dynamic Tobit model; see equations (1-2) of the text.

The sample period is 1998-2008; the dependent variable is governance_aid $(i, t)$.

\begin{tabular}{lcc} 
& coef. & t ratio \\
governance_aid $(i, t-1)$ & 0.3487 & $7.21^{* * *}$ \\
governance_aid $(i, t-2)$ & 0.2223 & $5.48^{* * *}$ \\
governance_aid $(i, t-3)$ & 0.0968 & $2.76^{* * *}$ \\
governance_aid $(i, 0)$ & 0.1612 & $3.00^{* * *}$ \\
finalist $(i, t)$ & 0.6142 & $2.00^{* *}$ \\
finalist $(i)$ & 3.8626 & $2.11^{* *}$ \\
s.d. of random effect: $\sigma_{\xi}$ & 0.9997 & $4.75^{* * *}$ \\
s.d. of residual: $\sigma_{v}$ & 1.7526 & $38.11^{* * *}$ \\
observations & \multicolumn{2}{c}{1496} \\
countries & \multicolumn{2}{c}{136}
\end{tabular}

*** significant at the $1 \%$ level; ** significant at the $5 \%$ level. 
Table 3: Dynamic Panel Estimates of Governance Aid Effects Using voice

See equations (3-4) of the text. The sample period is 2003-2008; the dependent variable is voice (i,t)

\begin{tabular}{|c|c|c|c|c|c|c|c|c|c|c|}
\hline \multirow[t]{2}{*}{ moment conditions on: } & \multicolumn{2}{|c|}{$\begin{array}{c}\text { voice }(i, 0) \geq-0.1(A) \\
\Delta \varepsilon \text { and } \varepsilon\end{array}$} & \multicolumn{2}{|c|}{$\begin{array}{c}\text { voice }(i, 0) \geq-0.1(B) \\
\Delta \varepsilon \text { and } \varepsilon\end{array}$} & \multicolumn{2}{|c|}{$\begin{array}{c}\text { voice }(i, 0)<-0.1(C) \\
\Delta \varepsilon \text { and } \varepsilon\end{array}$} & \multicolumn{2}{|c|}{$\begin{array}{c}\text { voice }(i, 0)<-0.1(D) \\
\varepsilon\end{array}$} & \multicolumn{2}{|c|}{$\begin{array}{c}\text { voice }(i, 0)<-0.1(E) \\
\Delta \varepsilon \text { and } \varepsilon\end{array}$} \\
\hline & coef. & tratio & coef. & tratio & coef. & tratio & coef. & tratio & coef. & tratio \\
\hline voice $(i, t-1)$ & 0.7720 & $9.05 * * *$ & 0.7685 & $10.34 * * *$ & 0.9697 & $28.02 * * *$ & 0.9875 & $27.75 * * *$ & 0.9249 & $22.16^{* * *}$ \\
\hline governance_aid $(i, t-1)$ & -0.0188 & $-2.34 * *$ & -0.0168 & $-1.88^{*}$ & -0.0035 & -0.75 & -0.0061 & -0.93 & -0.0088 & -1.60 \\
\hline population $(i, t-1)$ & -0.0001 & 0.00 & 0.0001 & 0.00 & -0.0072 & -0.15 & -0.0020 & -0.04 & -0.0094 & -0.42 \\
\hline disasters $(i, t)$ & & & -0.0063 & $-1.92 *$ & & & & & -0.0008 & -0.34 \\
\hline income $(i, t)$ & & & 0.0113 & 0.24 & & & & & -0.0027 & -0.11 \\
\hline total_aid $(i, t-1)$ & & & -0.0056 & -0.26 & & & & & 0.0471 & $2.85 * * *$ \\
\hline trade $(i, t)$ & & & -0.1222 & -1.47 & & & & & -0.0324 & -0.63 \\
\hline minerals $(i, t)$ & & & -0.1660 & -1.10 & & & & & -0.1690 & -1.54 \\
\hline s.d. of residual: $\sigma_{\varepsilon}$ & \multicolumn{2}{|c|}{0.024} & \multicolumn{2}{|c|}{0.026} & \multicolumn{2}{|c|}{0.017} & \multicolumn{2}{|c|}{0.017} & \multicolumn{2}{|c|}{0.014} \\
\hline Sargan test $p$-value & \multicolumn{2}{|c|}{0.513} & \multicolumn{2}{|c|}{0.570} & \multicolumn{2}{|c|}{0.017} & \multicolumn{2}{|c|}{0.361} & \multicolumn{2}{|c|}{0.275} \\
\hline $\operatorname{AR}(1)$ test $p$-value for $\Delta \varepsilon$ & \multicolumn{2}{|c|}{0.000} & \multicolumn{2}{|c|}{0.001} & \multicolumn{2}{|c|}{0.000} & \multicolumn{2}{|c|}{0.000} & \multicolumn{2}{|c|}{0.000} \\
\hline $\operatorname{AR}(2)$ test $\mathrm{p}$-value for $\Delta \varepsilon$ & \multicolumn{2}{|c|}{0.580} & \multicolumn{2}{|c|}{0.541} & \multicolumn{2}{|c|}{0.790} & \multicolumn{2}{|c|}{0.754} & \multicolumn{2}{|c|}{0.517} \\
\hline observations & \multicolumn{2}{|c|}{306} & \multicolumn{2}{|c|}{227} & \multicolumn{2}{|c|}{504} & \multicolumn{2}{|c|}{504} & \multicolumn{2}{|c|}{300} \\
\hline countries & \multicolumn{2}{|c|}{51} & \multicolumn{2}{|c|}{44} & \multicolumn{2}{|c|}{84} & \multicolumn{2}{|c|}{84} & \multicolumn{2}{|c|}{64} \\
\hline
\end{tabular}

*** significant at the $1 \%$ level; ** significant at the $5 \%$ level; * significant at the $10 \%$ level. 
Table 4: Dynamic Panel Estimates of Governance Aid Effects Using press

The coefficients are estimated using a dynamic Poisson model; see equations (5-6) of the text.

The sample period is 1996-2008; the dependent variable is press $(i, t)$

press $(i, t-1)$
press $(i, 0)$
governance_aid $(i, t-1)$
governance_aid $(i, 0)$
population $(i, t-1)$
population $(i)$
observations
countries

\begin{tabular}{lc}
\multicolumn{2}{l}{ press $(i, 0) \leq 35(\mathrm{~A})$} \\
coef. & t ratio \\
0.0254 & $24.23^{* * *}$ \\
0.0102 & $6.42^{* * *}$ \\
0.0104 & $2.27 * *$ \\
-0.0027 & -0.67 \\
-0.1715 & -0.68 \\
0.1754 & 0.70 \\
533 & \\
41 &
\end{tabular}

$\begin{array}{cc}\text { press }(i, 0) & >35(B) \\ \text { coef. } & \text { tratio } \\ 0.0159 & 38.07^{* * *} \\ -0.0010 & -2.35^{* *} \\ -0.0004 & -0.26 \\ -0.0009 & -0.60 \\ -0.0254 & -0.32 \\ 0.0251 & 0.31 \\ 1227 & \\ 95 & \end{array}$

*** significant at the $1 \%$ level; $* *$ significant at the $5 \%$ level. 
Table A1: Random-Effects Models of voice

See equation (A1) of Appendix 3.

The sample period is 2002-2008; the dependent variable is voice (i,t).

\begin{tabular}{|c|c|c|c|c|c|c|c|}
\hline \multirow[b]{3}{*}{ governance_aid (i,t-1) } & \multicolumn{2}{|c|}{$\begin{array}{l}\text { Random Effects } \\
\text { model (A) }\end{array}$} & \multicolumn{2}{|c|}{$\begin{array}{c}E C 2 S L S-R E \\
\text { model }(B)\end{array}$} & \multicolumn{3}{|c|}{$\begin{array}{c}E C 2 S L S-R E \\
\text { model }(C)\end{array}$} \\
\hline & coef. & tratio & coef. & & & tratio & \\
\hline & 0.0098 & $2.80 * * *$ & 0.0793 & $1.97 * *$ & 0.0337 & 2.28 & $* *$ \\
\hline population $(i, t-1)$ & -0.1810 & $-6.15 * * *$ & -0.2196 & $-3.15 * * *$ & -0.1159 & -2.82 & $* *$ \\
\hline disasters $(i, t)$ & & & & & 0.0008 & 0.44 & \\
\hline minerals $(i, t)$ & & & & & -0.6779 & -4.25 & $* * *$ \\
\hline French colony (i) & & & & & -0.0398 & -0.20 & \\
\hline British colony (i) & & & & & 0.2860 & 1.71 & $*$ \\
\hline European (i) & & & & & -0.5942 & -2.13 & $* *$ \\
\hline Asian (i) & & & & & -0.6240 & -2.76 & $* * *$ \\
\hline former Soviet (i) & & & & & -1.0930 & -3.40 & $* * *$ \\
\hline Mideast (i) & & & & & -0.9682 & -3.59 & $* * *$ \\
\hline African (i) & & & & & -0.7643 & -3.72 & $* * *$ \\
\hline $\mathrm{R}^{2}$ within countries & \multicolumn{2}{|c|}{0.006} & \multicolumn{2}{|c|}{0.003} & \multicolumn{3}{|c|}{0.005} \\
\hline $\mathrm{R}^{2}$ between countries & \multicolumn{2}{|c|}{0.196} & \multicolumn{2}{|c|}{0.224} & \multicolumn{3}{|c|}{0.516} \\
\hline $\mathrm{R}^{2}$ overall & \multicolumn{2}{|c|}{0.182} & \multicolumn{2}{|c|}{0.181} & \multicolumn{3}{|c|}{0.486} \\
\hline observations & \multicolumn{2}{|c|}{1351} & \multicolumn{2}{|c|}{1351} & \multicolumn{3}{|c|}{928} \\
\hline countries & \multicolumn{2}{|r|}{136} & \multicolumn{2}{|r|}{136} & \multicolumn{3}{|c|}{117} \\
\hline
\end{tabular}

$* * *$ significant at the $1 \%$ level; ** significant at the $5 \%$ level; * significant at the $10 \%$ level. 